\title{
Three new taxa, two new combinations and thirty-one lectotypifications in several Lauraceae genera from Peninsular Malaysia
}

\author{
R.P.J. de Kok \\ Honorary Research Associate, \\ Singapore Botanic Gardens, National Parks Board, \\ 1 Cluny Road, 259569 Singapore \\ rogier.dekok@yahoo.com
}

\begin{abstract}
Three new taxa of Lauraceae are described, two new species: Lindera kochummenii de Kok and Machilus kochummenii de Kok, and a new subspecies, Actinodaphne sesquipedalis Hook.f. \& Thoms. ex Meisn. subsp. glabra Kochummen ex de Kok. In addition, two new combinations are made: Machilus declinata (Blume) de Kok and Phoebe scortechinii (Gamble) Kochummen ex de Kok, and thirty-one names are lectotypified, including one second-step lectotypification.
\end{abstract}

Keywords. Actinodaphne, Lindera, Litsea, Machilus, Neolitsea, Peninsular Malaysia, Phoebe

\section{Introduction}

Several genera of the Lauraceae have recently been revised for the Flora of Peninsular Malaysia (Actinodaphne Nees, Endiandra R.Br., Lindera Thunb., Machilus Rumphius ex Nees and Phoebe Nees) in addition to the revisions for other genera already published (de Kok, 2016a, 2016b, 2016c, 2019). In Peninsular Malaysia, there are eleven species of Actinodaphne, nine species each of Lindera and Endiandra, and five each of Machilus and Phoebe. The inclusion of Machilus is new for the region. The delimitation of genera within the Persea Mill. group has always been difficult. The genus Machilus was first proposed by Rumphius (1743) and this name was later validated by Nees von Esenbeck (1831). Machilus has been recognised as a part of Persea for a long time, but this has often been controversial (see Kostermans, 1962; Rohwer, 1993; van der Werff, 2001; Li et al., 2008). A recent molecular phylogenetic analysis of the Persea group (Rohwer et al., 2009) has shown that the Asian clade of Persea should be treated as a separate genus, Machilus, not as a part of Persea. It is closely related to the Alseodaphne-Phoebe clade, which also includes Dehaasia, Nothaphoebe and the remaining species of Persea from America and Macaronesia. Therefore, all Persea species from Peninsular Malaysia are now recognised as belonging to Machilus.

Full descriptions, keys and notes on distribution and ecology will be given in the forthcoming account in the Flora of Peninsular Malaysia. It became clear during the preparation of these revisions that three taxa require new names, three new generic 
combinations need to be made and thirty-one names need to be lectotypified. The aim of this paper is to make and discuss these changes.

The revisions are based on herbarium collections from Peninsular Malaysia and Singapore that are now housed at the Natural History Museum, London (BM), the Royal Botanic Gardens, Kew (K and K-W), the Forest Research Institute of Malaysia (KEP) and the Singapore Botanic Gardens (SING). Type material not available at those institutions was studied online via JSTOR (https://plants.jstor.org/plants) and accessed in December 2017. For the conservation assessments, all Areas of Occupancy (AOO) and Extents of Occurrence (EOO) were calculated using the standard settings of the GeoCAT (http://geocat.kew.org) on 9 March 2018.

\section{New names}

Actinodaphne sesquipedalis Hook.f. \& Thoms. ex Meisn. subsp. glabra Kochummen ex de Kok, subsp. nov.

Actinodaphne sesquipedalis subsp. glabra differs from A. sesquipedalis subsp. sesquipedalis in having glabrous leaves and petioles (rather than silky hairy ones) and the two subspecies are geographically distinct. - TYPE: [Peninsular Malaysia] Ulu Terengganu, Telemong Forest Reserve, Bukit Batu Kota, 16 September 1969, Suppiah FRI 11412 (holotype KEP [260409]). (Fig. 1-2)

Actinodaphne sesquipedalis Hook.f. \& Thoms. ex Meisn. var. glabra Kochummen, Gard. Bull. Singapore 43: 23 (1992), nom. inval.; Tanaros et al., Thai J. Bot. 2: 18-19 (2010).

Tree 4.5-10 m high, DBH 10-30 cm; bark smooth, grey to dark brown, inner bark yellow to brown, sapwood light yellow to brown. Twigs stout, $6.5-18 \mathrm{~mm}$ thick, round in cross-section, glabrous to sparsely hairy; hairs appressed, yellowish; terminal leaf buds covered with large green leaf-like scales which resemble under-sized foliage leaves, ovate to elliptic, 2-8 cm long, glabrous to pubescent. Leaves in whorls of 5-8; leaf blade coriaceous, elliptic-oblanceolate, 30-60 ×9-18.5 cm, apex acute, base cuneate, secondary veins $12-16$ pairs, brochidodromous, tertiary veins scalariform, upper surface glabrous when mature, yellowish velutinous when young, midrib raised to sunken, secondary veins raised, tertiary veins distinct, green, shining, lower surface glabrous when mature, yellowish velutinous when young, midrib and secondary veins raised, tertiary veins distinct, sometimes glaucous; petiole half-terete, $2-5.5 \mathrm{~cm}$ long, glabrous, slightly swollen at base. Inflorescences pseudo-umbellate, on bare twigs between leaves, 0.8-1 cm long; bracts ovoid, 4-7 × 2.9-6.6, apex rounded, velutinous outside, glabrous inside; infructescence with 1-15 fruits. Flowers yellow to white; male flowers: perianth lobes ovate, 3-5 × 1.6-2.6 mm, velutinous outside, glabrous inside; stamens 2.2-6 mm long, sparsely hairy, anthers 1.4-2.5 mm long; female flowers: perianth lobes ovate, $2.6-3 \times 2-2.5 \mathrm{~mm}$, velutinous outside, glabrous 


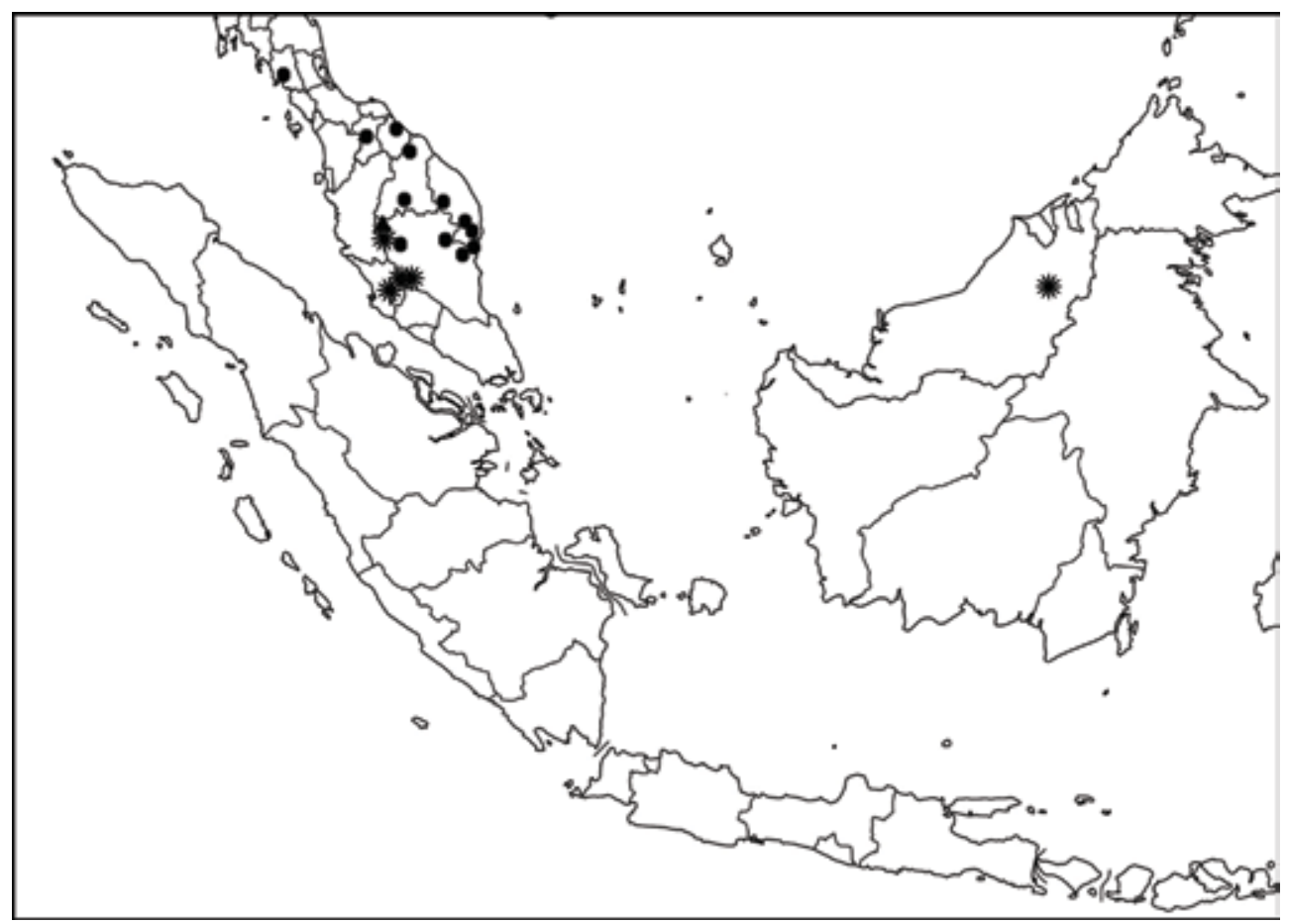

Fig. 1. Distribution of Actinodaphne sesquipedalis subsp. glabra ( $\bullet$ ), Lindera kochummenii ( ) and Machilus kochummenii ( $\boldsymbol{\Delta}$ ).

inside; ovary ovoid, c. $0.6 \mathrm{~mm}$ diam., glabrous, style c. $0.5 \mathrm{~mm}$ long, glabrous, stigma peltate. Fruits globose, 1-2.3 $\times 2-3 \mathrm{~cm}$, apex rounded and depressed, surface smooth, glabrous, bright yellow to finally purple or black when mature; cupule shallow to covering half of fruit, 7-16 $\times 2.6-9 \mathrm{~mm}$, woody, smooth or with warts, margin entire, glabrous; fruit stalk slightly swollen, $3-3.2 \mathrm{~mm}$ thick, glabrous.

Distribution. Peninsular Thailand and Peninsular Malaysia. In Peninsular Malaysia it is only known from the eastern states: Terengganu, Kelantan and Pahang. In Peninsular Thailand, it is known from the provinces of Ranong, Trang, Yala and Narathiwat (Tanaros 2010: 19) (see Fig. 1).

Ecology. Growing in primary to secondary lowland to hill forests, sometimes along rivers and on shale or granite, at 30-550 m altitude. Flowering from September to October; fruiting from February to October.

Provisional IUCN conservation assessment. This species has been collected 11 times in the states of Terengganu, Kelantan and Pahang in Peninsular Malaysia and six times in Thailand. An analysis of the EOO gives a conservation assessment of Least Concern, but an analysis of the AOO gives an assessment of Endangered. Given the 
intensive logging and landscape modification that has occurred in the region in the last fifty years, this taxon should be considered to be Endangered (EN B2ab(ii,iii)).

Additional specimens examined. PENINSULAR MALAYSIA: Kelantan: Gua Musang, 31 May 1931, Henderson SFN 24831 (KEP); Gua Musang, 4 Jul 1935, Henderson SFN 29513 (KEP); Jeli, 7 Oct 1992, Ahmad Zainudin AZ 4307 (KEP). Pahang: Kuantan, Bukit Goh Forest Reserve, 15 Feb 1934, Ismail FMS 17324 (KEP); Kuantan, Bukit Galing, 11 Aug 1977, Chan FRI 23997 (KEP); Lipis, Ulu Serau, Sungai Serunai, 17 Oct 1931, Osman FMS 28227 (KEP); Jerantut, Taman Negara, Kuala Terengan, 13 Aug 1972, Mohd. Shaw MS 2646 (KEP). Terengganu: Kemaman, Bukit Kajang, 28 Jun 1932, Corner SFN 25938 (KEP); Hulu Terengganu, Ulu Brang, Jul 1937, Moysey SFN 33877 (KEP); Hulu Telemong, 15 Sep 1969, T. Suppiah FRI 11395 (KEP).

Notes. In the original description of this taxon by Kochummen (1992), no type specimen was designated. This means that in accordance with the International Code of Nomenclature (see Turland et al., 2018: Art. 40.1) this name is invalid. The designation of a type here corrects this oversight.

This taxon differs in at least one character from the type variety. It is also geographically distinct, as it found along the east coast in Peninsular Thailand and in Peninsular Malaysia, whereas Actinodaphne sesquipedalis subsp. sesquipedalis is found in Cambodia, Myanmar, Thailand and Borneo and is restricted in Penninsular Malaysia to the west coast and its southern parts. This taxon differs sufficiently in its morphology and distribution that is appropriate to recognise it at subspecies level.

\section{Lindera kochummenii de Kok, sp. nov.}

Lindera kochummenii differs from L. concinna Ridl. in having velutinous twigs (rather than glabrous to sparsely hairy twigs), longer terminal leaf buds (4-4.3 mm, rather than 1.6-2.6 mm long) and longer petioles (9-11 mm, rather than 5-7.5 mm long). TYPE: Peninsular Malaysia, Bentong, Gunung Ulu Kali, 10 April 2013, A.R. Ummul Nazrah FRI 78321 (holotype KEP [225936]; isotypes K [no barcode]). (Fig. 1, 3)

Lindera concinna Ridl. var. reticulata Kochummen, Gard. Bull. Singapore 43: 25 (1992), nom. inval.; Kochummen, Tree Fl. Malaya 4: 146 (1989).

Shrub or tree, 1.5-3 m tall; bark brown-orange to dark brown. Twigs slender, 1.8-3 $\mathrm{mm}$ thick, round in cross-section, velutinous, dark brown; hairs appressed, whitish; terminal leaf buds ovoid, 4-4.3 mm long, apex rounded to acute, velutinous, sometimes margin glabrous. Leaves alternate; leaf blade leathery, elliptic to ovate, $2.2-7 \times 1.3-3$ $\mathrm{cm}$, apex rounded to acute, base cuneate, margins straight, triplinerved, secondary veins 3-5 pairs, pinnate more distally, tertiary veins scalariform-reticulate, upper surface glabrous, sometime sparsely hairy on midrib when young, midrib flattened to sunken, secondary veins raised to flattened, tertiary veins distinct, (dark) green, lower surface glabrous, sometimes sparsely hairy on lamina and midrib when young, midrib 


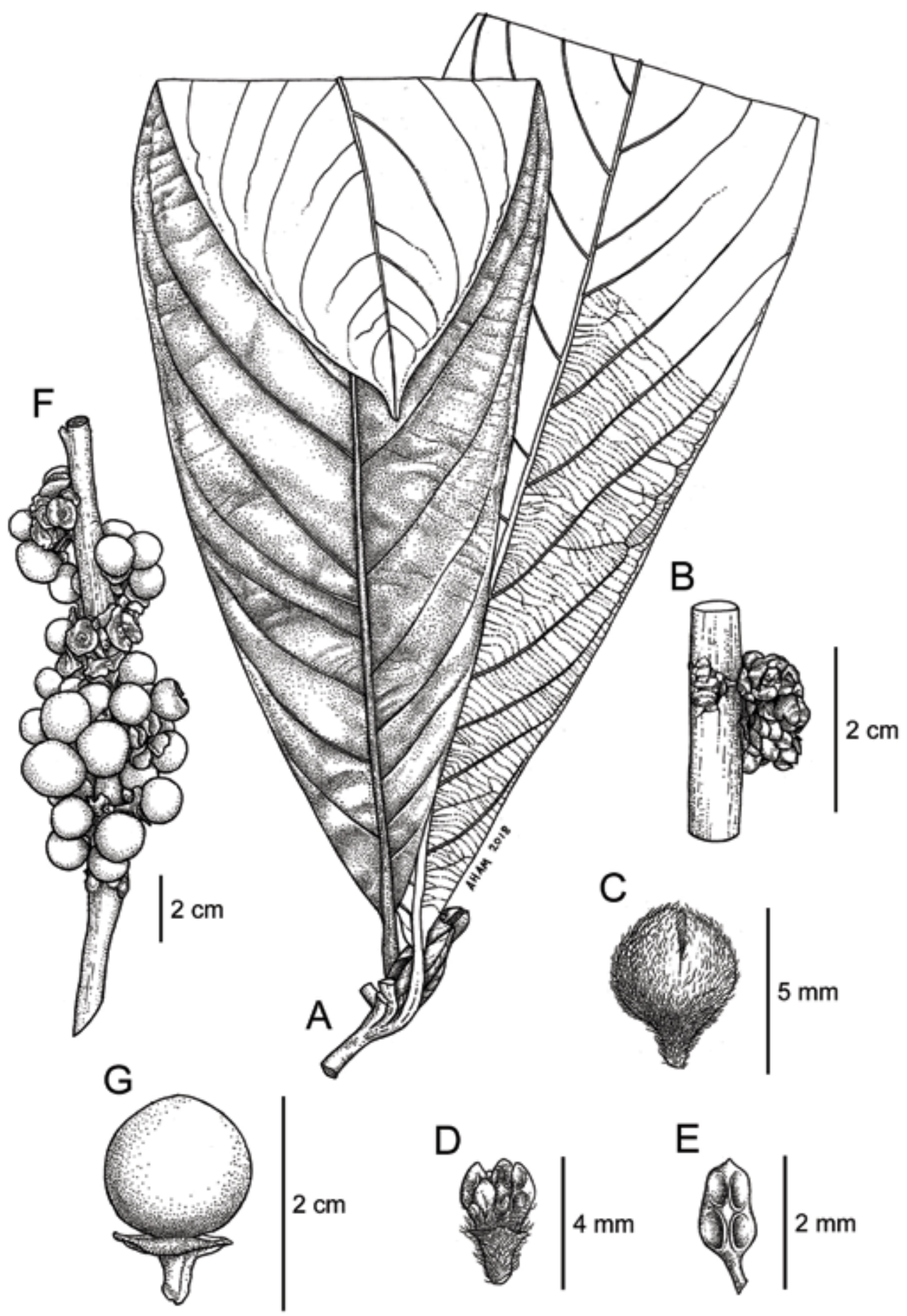

Fig. 2. Actinodaphne sesquipedalis subsp. glabra Kochummen ex de Kok. A. Habit. B. Inflorescence. C. Umbel. D. stamens. E. Anther. F. Infructescence. G. Fruit. A from Suppiah FRI 1141; B-E from Suppiah FRI 11412; F-G from Moysey \& Kiah SFN 33877. Reproduced with kind permission of the Forest Research Institute Malaysia. 
and secondary veins raised, tertiary veins distinct, glaucous; petiole half-terete, 9-11 $\mathrm{mm}$ long, slender, sparsely hairy. Inflorescences pseudo-umbellate, $0.3-0.4 \mathrm{~cm}$ long, 1-5 flowers per umbel, in axils of leaves, sparsely hairy; umbels $1.4-1.8 \mathrm{~mm}$ in diam; bracts 2, ovoid, 2.3-3 × 1.5-2 mm glabrous; bracteoles elliptic, 2.1-2.3 × 1.2-1.7 $\mathrm{mm}$, apex rounded to acute, glabrous to velutinous. Flowers pale yellow to white, scentless; male flowers: perianth lobes elliptic, 2-3 × 1-1.3 mm, apex acute, sparsely hairy outside and inside; stamens 2-4 mm long, sparsely hairy, anthers 0.6-0.7 mm long; female flowers: perianth lobes elliptic, $0.8-0.9 \times 0.6-0.7 \mathrm{~mm}$, apex rounded to acute, densely hairy outside, sparsely hairy inside; ovary $0.5-0.6 \mathrm{~mm}$, glabrous, style $0.6-0.8 \mathrm{~mm}$ long, stigma $0.2-0.3 \mathrm{~mm}$ long, two lobed, white. Fruits (immature) ellipsoid, 6-9 × 5-8 mm, apex acute, surface smooth, glabrous; cupule membranous, perianth lobes $0.8-1.4 \times 0.9-1 \mathrm{~mm}$ with rounded apices, persistent, erect; fruit stalk slender, up to $0.8 \mathrm{~mm}$ thick.

Distribution. Peninsular Malaysia and Borneo. In Peninsular Malaysia, it is recorded from Pahang and Selangor and in Borneo it is known from Sarawak (see Fig. 1).

Ecology. Growing in montane and heath forests or in open Leptospermum woodlands, sometimes over granite or on peat, at 1370-2060 m altitude. Flowering in November to June; fruiting from June to August.

Provisional IUCN conservation assessment. This species has been collected many times in Pahang and Selangor in Peninsular Malaysia and a handful of times in Sarawak. An analysis of the EOO gives a conservation assessment of Vulnerable, but an analysis of the AOO gives an assessment of Endangered. Given the intensive logging and landscape modification that has occurred in Malaysia in the last fifty years, this species should be considered to be Endangered (EN B2ab(ii,iii)).

Additional specimens examined. PENINSULAR MALAYSIA: Pahang: Temerloh, Gunung Benom, 13 Nov 2009, Mohd. Hairul FRI 69874 (K, KEP); Genting Highlands, Bentung, 16 Jan 1994, Noorsiha et al. FRI 41055 (KEP); Genting Highlands, Bentung, 17 Jan 1994, Noorsiha et al. FRI 41070 (KEP); Genting Highlands, 27 Jan 1974, Ng FRI 22001 (KEP); Gunung Benon, Krau Game Reserve, 17 Mar 1967, Whitmore FRI 3238 (KEP); Gunung Ulu Kali, 3 Sep 1970, Whitmore FRI 15408 (KEP); Gunung Benon, 19 Mar 1967, Whitmore FRI 3287 (KEP); Bukit Fraser 14 Sep 1933, Symington 29494 (KEP); Bukit Fraser, Pine tree hill, 18 Aug 1960, Burkill \& Noor HMB 2365 (KEP); Fraser's Hill, 31 Jul 1949, Anonymous 64934 (KEP); Fraser Hill's, 14 Nov 1937, Symington 45040 (KEP). Selangor: Ulu Selangor, 3 Nov 1940, Symington 56676 (KEP); Ulu Kali, 11 Jun 193, Mohd Shah \& Mohd Ali MS 2968 (KEP); Ulu Kali, 13 Feb 1968, Whitmore FRI 4706 (KEP); Summit of Ulu Kali, 11 Jun 1973, Mohd Shah \& Mohd Ali MS 2941 (KEP); Ulu Kali, 3 Jul 1981, Putz FRI 30965 (KEP).

Notes. This taxon differs in at least three independent characters from its morphologically closest relative Lindera concinna. It is also geographically distinct, as it is found in Peninsular Malaysia in the central mountain chain in Pahang and in Sarawak in Borneo, whereas L. concinna is restricted to the Taman Negara area in Pahang and the 

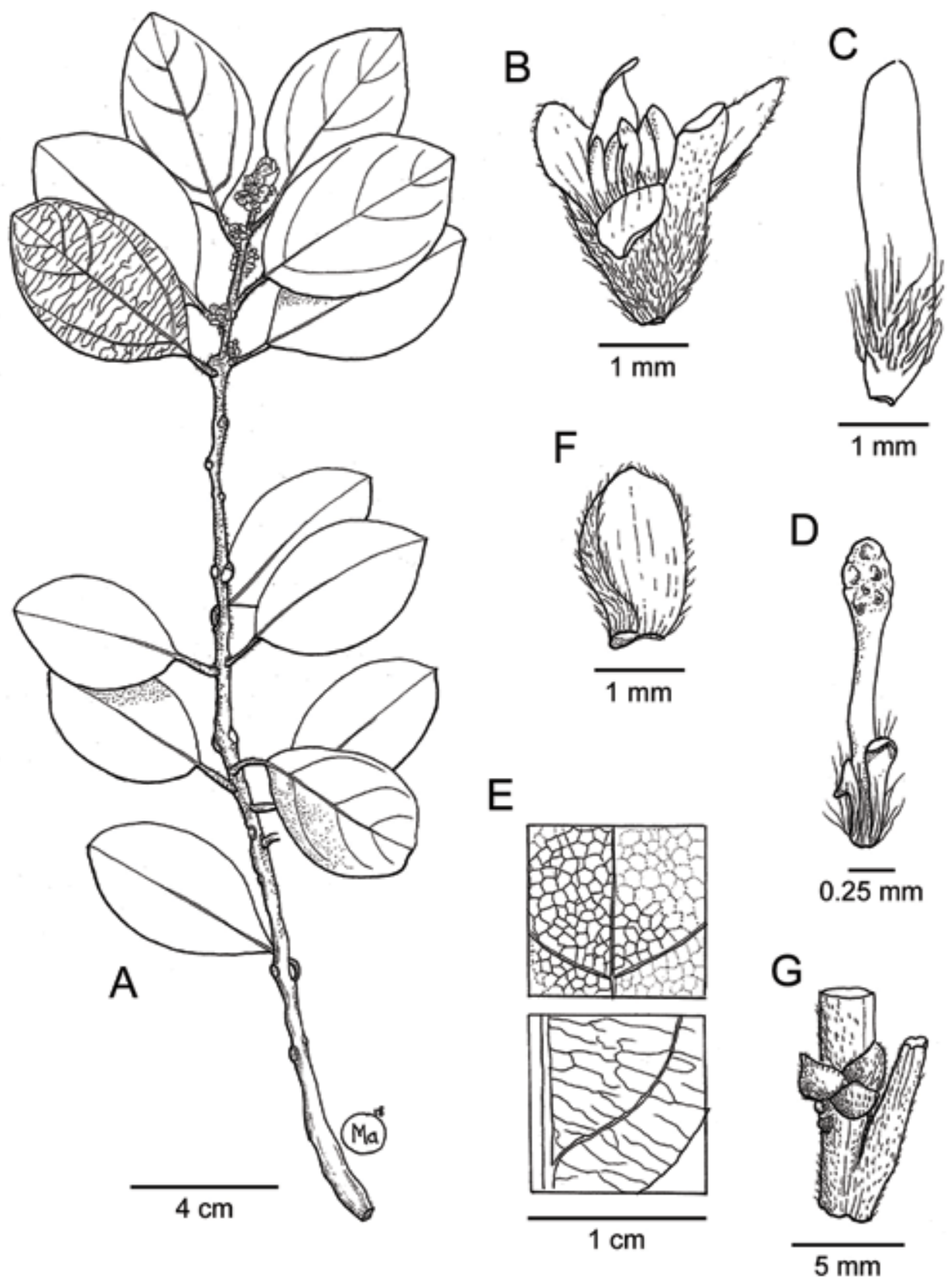

Fig. 3. Lindera kochummenii de Kok. A. Habit. B. Flower. C. Perianth lobe of male flower. D. Stamen with anther. E. Details of lower leaf surfaces. F. Perianth lobe of female flower. G. Terminal leaf buds reaming on twigs. All from T.C.Whitmore FRI 20464. Reproduced with kind permission of the Forest Research Institute Malaysia. 
Gua Musang area in Kelantan. The taxon was first recognised by Kochummen (1992) as Lindera concinna var. reticulata. However, as he did not select a type, his name is invalid (Turland et al., 2018: Art. 40.1). Lindera kochummenii differs sufficiently in its morphology and distribution that it is appropriate to recognise it at species level and it is named here after K.M. Kochummen, who first recognised it as distinct.

\section{Machilus kochummenii de Kok, sp. nov.}

Machilus kochummenii de Kok differs from Machilus rimosa Blume in having smaller leaves $(3-9 \times 1.5-3 \mathrm{~cm}$, rather than $6-19 \times 3-8 \mathrm{~cm})$ with $5-8$ pairs of secondary veins (rather than 8-10 pairs). - TYPE: [Peninsular Malaysia] Pahang, Cameron Highlands, 12 April 1930, Henderson SFN 23544 (holotype KEP [131240]; isotype KEP [131239]). (Fig. 1, 4)

Persea sp. nov. '4', Kochummen, Tree F1. Malaya 4: 174 (1989).

Tree up to $30 \mathrm{~m}$ tall. Twigs slender, 3.3-4.8 $\mathrm{mm}$ thick, angular to rounded in crosssection, glabrous, blackish, with prominent ring-like scars left by terminal leaf buds and leaves; terminal leaf buds ovoid, 1-1.4 mm long, apex acute, glabrous. Leaves alternate; leaf blade thickly leathery, elliptic to obovate, $3-9 \times 1.5-3 \mathrm{~cm}$, apex acute, base cuneate, secondary veins 5-8 pairs, curving near margin, brochidodromous, tertiary veins reticulate, upper surface glabrous, midrib sunken, secondary veins raised to flat, tertiary veins indistinct, lower surface glabrous, midrib and secondary veins raised, tertiary veins distinct; petiole channelled, 4-8 $\mathrm{mm}$ long, slender, glabrous. Inflorescence paniculate-cymose, 6-7 cm long, axillary, axis smooth, glabrous. Flowers unknown. Fruit globose 7-10 × 7.5-8.8 cm, apex rounded, surface smooth, glabrous, purplish when mature; cupule shallow, perianth lobes elliptic, 4-4.4 × 1.9 $2.2 \mathrm{~mm}$, with acute apices, persistent, reflexed, hairy; fruit stalk slightly enlarged, up to $1.8 \mathrm{~mm}$ thick.

Distribution. Endemic to Peninsular Malaysia (Pahang, Cameron Highlands) (Fig. 1).

Ecology. Growing in montane forests at 1400-1460 m altitude. Flowering time unknown; fruiting from April to May.

Provisional IUCN conservation assessment. This taxon is only known from two gatherings from the Cameron Highlands in Pahang state at 1400-1460 m altitude. No new specimens have been collected since 1931. Analyses of both the EOO and AOO give a conservation assessment of Critically Endangered. Given this and the lack of specimens since 1931, this species must be considered to be Critically Endangered (CR B2ab(ii,iii)). 


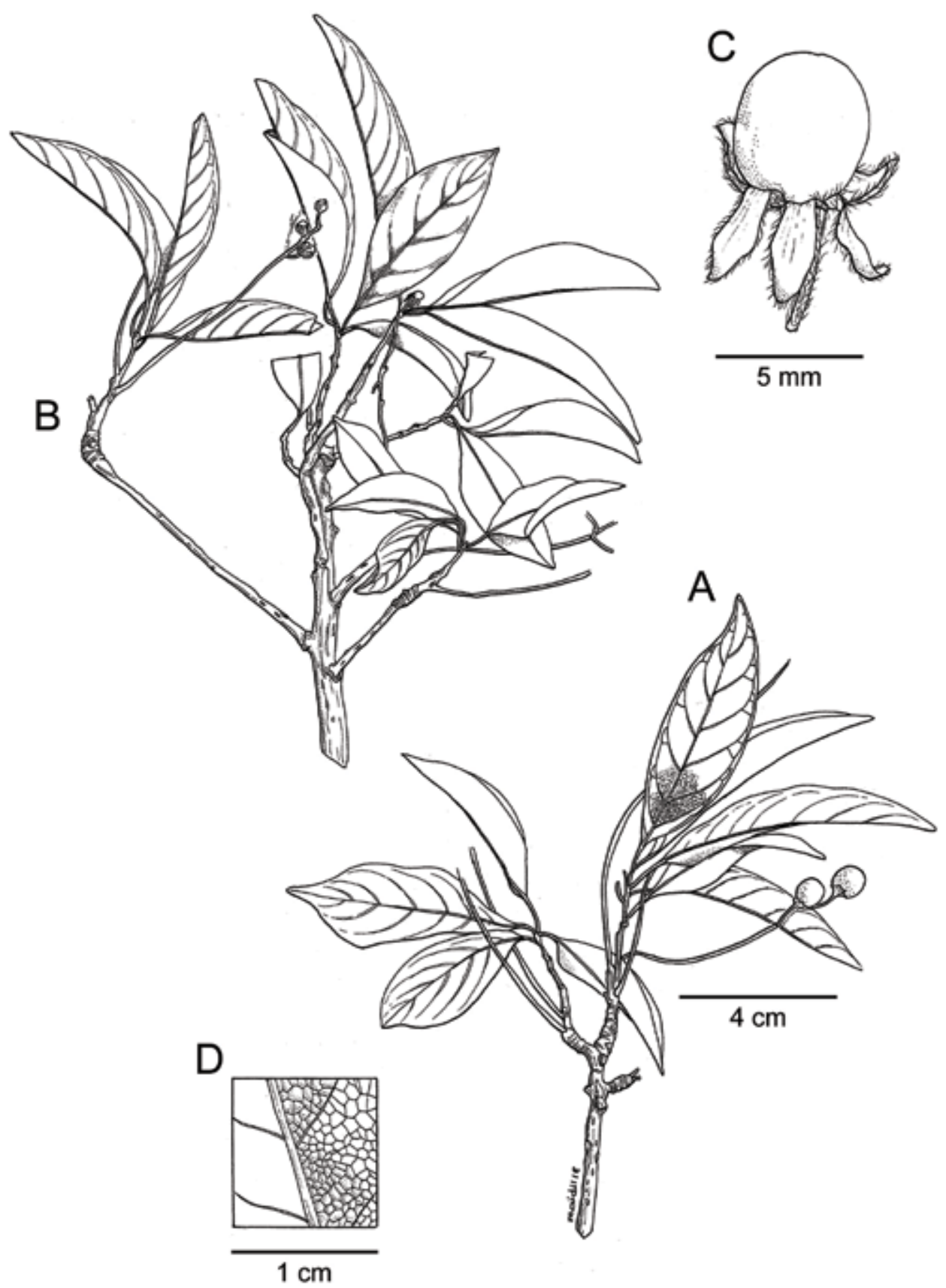

Fig. 4. Machinus kochummenii de Kok. A. Habit with fruits. B. Habit with flowers. C. Fruits with calyx lobes. D. Detail of lower leaf surface. All from Henderson SFN 23544. Reproduced with kind permission of the Forest Research Institute Malaysia. 
Notes. Given that most genera in the Lauraceae are defined on the basis of floral characters, it is somewhat problematic to describe a new species in the family without any flowers. However, this one clearly belongs to Machilus as it has globose fruits with perianth lobes that are recurved, and inflorescences which are paniculate-cymose of type 2 (see van der Werff, 2001). This species is distinct from the others in the genus in Peninsular Malaysia and has been recognised as different since 1989 (Kochummen, 1989: 174).

The species is named after K.M. Kochummen (1931-1999) who first recognised this taxon.

\section{New combinations}

Machilus declinata (Blume) de Kok, comb. nov. - Ocotea declinata Blume, Bijdr. Fl. Ned. Ind. 11: 572 (1826). - Persea declinata (Blume) Kosterm., Reinwardtia 9: 111 (1974); Kochummen, Tree Fl. Malaya 4: 173 (1989). - Phoebe declinata (Blume) Nees, Syst. Laur. 114 (1836); Ridley, Fl. Malay Penins. 3: 104 (1924). - TYPE: [Indonesia, Java] Mt Salak, December 1822, C.L. Blume s.n. (lectotype L [L0036918], designated here).

In the Asian species of Machilus (previously in Persea) the calyx lobes are persistent and spreading to reflexed in fruit, while in Phoebe they are persistent and pressed against the fruit (van der Werff, 2001). In Peninsular Malaysia some Machilus species can have erect to spreading lobes, but these are then always membranous, often with a reflexed apex in fruit, while in Phoebe these erect calyx lobes are fleshy and hard and always have an erect apex in fruit. Persea declinata (Blume) Kosterm. has erect to spreading membranous calyx lobes, with apices that are often reflexed in fruit. Given that the Asian species of Persea are now being recognised as part of a distinct genus (see notes under Machilus kochummenii), this name is best transferred to Machilus.

Among the four specimens in Leiden that were collected by Blume, only one has both the month and locality mentioned in the original description (Blume, 1826) on the label and this specimen is designated here as the lectotype.

Phoebe scortechinii (Gamble) Kochummen ex de Kok, comb. nov. - Machilus scortechinii Gamble, Bull. Misc. Inform. Kew 1910: 226 (1910); Ridley, Fl. Malay Penins. 3: 103 (1924); Kostermans, Reinwardtia 8: 128 (1970). - Phoebe scortechinii (Gamble) Kochummen, Tree Fl. Malaya 4: 177 (1989), nom. inval. - TYPE: [Peninsular Malaysia] Perak, B. Scortechini 492 (lectotype K [K000778875], designated here; isolectotype $\mathrm{K}$ [no barcode]).

The combination made by Kochummen in 1989 was invalid as he did not mention the original reference for the basionym (see Turland et al., 2018: Art. 41.1). A new combination is therefore made here. 
Two gatherings were mentioned in the original description of Machilus scortechinii by Gamble (1910): Scortechini 492 and King's Collector 8413, both of which are from Perak in Peninsular Malaysia. As Gamble was working at Kew at the time he described this species, only the $\mathrm{K}$ material is considered for lectotypification. The sheet chosen as the lectotype has dissections and drawings on a card which were signed by Gamble, as was typical for this author.

\section{Lectotypifications}

Actinodaphne cuspidata Gamble, Bull. Misc. Inform. Kew 1910: 314 (1910); Ridley, Fl. Malay Penins. 3: 111 (1924); Kochummen, Tree Fl. Malaya 4: 104 (1989). TYPE: [Peninsular Malaysia] Perak, Ulu Bera, August 1886, King's Collector 10797 (lectotype K [K000793059], designated here; isolectotype K [K000793058]).

Only one gathering was mentioned in the original description of Actinodaphne cuspidata (Gamble, 1910): King's Collector 10797. Two specimens of this gathering at $\mathrm{K}$ are morphologically very similar. However, one has a card in an envelope with the characteristic and detailed floral dissection and drawings made and signed by Gamble, and this specimen is designated here as the lectotype.

Actinodaphne fragilis Gamble, Bull. Misc. Inform. Kew 1910: 315 (1910); Ridley, F1. Malay Penins. 3: 111 (1924); Kochummen, Tree Fl. Malaya 4: 104 (1989). - TYPE: [Peninsular Malaysia] Perak, Ulu Bubong, September 1886, King's Collector 10904 (lectotype K [K000793060], designated here; isolectotypes BM [BM000799239], P [P00745192]).

Two gatherings were mentioned in the original description of Actinodaphne fragilis (Gamble, 1910): King's Collector 10743 and 10904. I have seen three specimens in various herbaria $(\mathrm{BM}, \mathrm{K}$ and $\mathrm{P}$ ) of the second gathering and one at $\mathrm{K}$ of the first. As Gamble worked at Kew when he wrote his paper, only the K material is considered for lectotypification. In additon, one of the K specimens of King's Collector 10904, has a card with the characteristic and detailed floral dissection and drawings made and signed by Gamble. This specimen K000793060 is designated here as the lectotype.

Actinodaphne maingayi Hook.f., Fl. Brit. Ind. 5: 151 (1886); Ridley, Fl. Malay Penins. 3: 108 (1924). - TYPE: [Peninsular Malaysia] Malacca, August 1865-1866, A.C. Maingay 1782 [Kew distribution nr. 1258] (lectotype K [K000793036], first step designated by Julia, Gard. Bull. Sing. 57: 77 (2005), second step designated here; isolectotype L [L0035469]). 
In her paper dealing with the species of Actinodaphne from Borneo (Julia, 2005), she selected a K collection, Maingay [Kew distribution nr.] 1258, as the lectotype of A. maingayi Hook.f. However, there are two sheets at $\mathrm{K}$ with this number: Maingay 1782 [Kew distribution nr. 1258], Malacca, Aug. 1865-1866 (K000793036], L) and Maingay 1999 [Kew distribution nr. 1258] Malacca, 1865-1866 (K [K000793035], picture at KEP; L). As only one of these can serve as the type, the specimen with flowers and a card with drawings and floral dissections made and signed by Gamble, is designated here in a second step lectotypification.

Actinodaphne malaccensis Hook.f., Fl. Brit. India 5: 148 (1886); Ridley, F1. Malay Penins. 3: 109 (1924); Kochummen, Tree Fl. Malaya 4: 105 (1989). - TYPE: [Peninsular Malaysia] Malacca, 1865-1866, A.C. Maingay 1995 [Kew distribution nr. 1259] (lectotype K [K000793043], designated here; isolectotypes K [K000793042], L [L0035470]).

Only one gathering was mentioned in the original description of Actinodaphne malaccensis (Hooker, 1886): Maingay 1995 [Kew distribution nr. 1259]. As Hooker worked at Kew when he wrote this paper, only the $\mathrm{K}$ material is considered for lectotypification. Of these, one has fruits and one has flowers. As fruits are more important than flowers in species recognition in this genus, the fruiting specimen, K000793043, is designated here as the lectotype.

Actinodaphne montana Gamble, Bull. Misc. Inform. Kew 1910: 312 (1910); Ridley, F1. Malay Penins. 3: 108 (1924); Kochummen, Tree Fl. Malaya 4: 105 (1989). - TYPE: [Peninsular Malaysia] Perak, near Larut, April 1882, King's Collector 2913 (lectotype $\mathrm{K}$ [no barcode], designated here; isolectotype K [K00793040], picture at KEP).

Two gatherings are mentioned in the original description of Actinodaphne montana (Gamble, 1910): King's Collector 2129 and 2913. As Gamble was working at Kew at the time he described this species and one of the K specimens of King s Collector 2913 has both fruits and imbricate terminal leaf buds, which are very characteristic for this species, this specimen is designated here as the lectotype.

Actinodaphne pruinosa Wall. ex Nees in Wallich, P1. Asiat. Rar. 2: 68 (1831); Ridley, Fl. Malay Penins. 3: 110 (1924); Kochummen, Tree Fl. Malaya 4: 106 (1989). - TYPE: [Peninsular Malaysia] Penang, 1822, N. Wallich 2584b (lectotype K-W [K001116508], designated here; isolectotypes BO, BM, E [E00413920], K [K000793046], L [L0035487]).

I could not find a specimen of Wallich $2584 \mathrm{~b}$ in the Nees von Esenbeck herbarium at GZU. Therefore I have selected the specimen in the Wallich herbarium in Kew as the lectotype for this name. 
Actinodaphne pruinosa var. kunstleri Gamble, J. Asiat. Soc. Bengal 75: 120 (1912); Ridley, Fl. Malay Penins. 3: 110 (1924). - TYPE: [Peninsular Malaysia] Perak, Larut, May 1884, King's Collector 6063 (lectotype K [no barcode]), designated here; isolectotypes BM, K 2x [K000793047 and one without a barcode], MEL [MEL2386443]).

Only one gathering was mentioned in the original description of Actinodaphne pruinosa var. kunstleri (Gamble, 1912): King's Collector 6063. There are three specimens at K and one each at BM and MEL. As Gamble worked at Kew when he described this taxon, only the $\mathrm{K}$ material is considered for lectotypification. Among these, one is sterile, one has only empty cupules, and the third has both fruits and cupules. This last specimen is designated here as the lectotype.

Actinodaphne ridleyi Gamble, Bull. Misc. Inform. Kew 1910: 312 (1910); Ridley, Fl. Malay Penins. 3: 109 (1924); Kochummen, Tree Fl. Malaya 4: 106 (1989). TYPE: [Peninsular Malaysia] Johore, Gunung Pulai, December 1905, H.N. Ridley 12165 (lectotype K [K000793045], designated here, picture at KEP; isolectotypes BM [BM001209856], SING [SING0058152]).

Two gatherings were mentioned in the original description of Actinodaphne ridleyi (Gamble, 1910): Ridley 12165 from Peninsular Malaysia and Haviland s.n. from Borneo. The specimen Ridley 12165 held at $\mathrm{K}$ has a card with the characteristic floral dissections and drawings made by Gamble when he was working at Kew. This specimen K000793045 is designated here as the lectotype.

Beilschmiedia glomerata Merr. var. tonkinensis Lecomte, Fl. Indo-Chine 5: 149 (1914). - TYPE: [Laos] Bassin d'Attopeu, 1875-1877, F.J. Harmand s.n. (lectotype P [P02002556], designated here; isolectotype K [no barcode]) P [P02002557, $\mathrm{P} 02002577])$.

Two gatherings were mentioned in the original description of Beilschmiedia glomerata var. tonkinensis (Lecomte, 1914): Harmand s.n. from Laos and Bon s.n. from Vietnam. As Lecomte was working at $\mathrm{P}$ at the time he described this taxon, only the $\mathrm{P}$ material is considered for lectotypification. I could not find the Bon specimen at $\mathrm{P}$, but one of the three Harmand specimens is designated here as the lectotype.

Cryptocarya wrayi Gamble, Bull. Misc. Inform. Kew 1910: 142 (1910); Ridley, F1. Malay Penins. 3: 77 (1924); Kochummen, Tree Fl. Malaya 4: 137 (1989). - TYPE: [Peninsular Malaysia] Perak, Larut, Gunung Bubu, March 1890, L. Wray 3853 (lectotype K [K001084616], designated here; isolectotypes K [K001084617], SING [SING0059144). 
There is only one gathering mentioned in the original description of Cryptocarya wrayi (Gamble, 1910): Wray 3853. As Gamble was working at Kew at the time he described this species, only the $\mathrm{K}$ material is considered for lectotypification. Two specimens with this number are at $\mathrm{K}$ and the one with the floral dissections and drawings on a card done by Gamble is designated here as the lectotype.

Endiandra kingiana Gamble, Bull. Misc. Inform. Kew 1910: 151 (1910); Ridley, Fl. Malay Penins. 3: 89 (1924); Kochummen, Tree Fl. Malaya 4: 142 (1989). - TYPE: [Peninsular Malaysia], Perak, Larut, August 1884, King's Collector 6487 (lectotype K [K000009818], designated here; isolectotypes BM [BM000799336], K [K000009820, K000009819], P [P00757134]).

Only one gathering was mentioned in the original description of Endiandra kingiana (Gamble, 1910): King's Collector 6487. Among the three specimens of this gathering at $\mathrm{K}$, only one has a well-developed inflorescence with floral dissections and drawings on a card made by Gamble. This specimen, K000009818, is selected here as the lectotype.

Endiandra macrophylla (Blume) Boerl., Handl. Fl. Ned. Ind. 3: 136 (1900); Kochummen, Tree Fl. Malaya 4: 142 (1989). - Dictyodaphne macrophylla Blume, Mus. Bot. 1(21): 332 (1851). - Actinodaphne macrophylla (Blume) Nees, Syst. Laur. 598 (1836). - TYPE: [Indonesia] Java, 'Huru mugmal', C.G.C. Reinwardt 226 (lectotype L [L0036397], designated here).

In the original description of Dictyodaphne macrophylla (Blume, 1851) the collection details can be translated as: "In the mountains of Java and in the mountains of Sumatra" and for which two local names are given 'Huru mugmal' and 'Huru kidang sundaice'. Several specimens are available at L for lectotypification but only one has some of the data from the original description on its label and this specimen, L0036428, is designated here as the lectotype.

Endiandra maingayi Hook.f., Fl. Brit. Ind. 5: 127 (1886); Ridley, Fl. Malay Penins. 3: 89 (1924); Kochummen, Tree Fl. Malaya 4: 142 (1989). - TYPE: [Peninsular Malaysia] Malacca, 24 July 1868, A.C. Maingay 2456 [Kew distribution nr. 1270] (lectotype K [K000009823], designated here; isolectotype K [no barcode]).

Only one gathering was mentioned in the original description of Endiandra maingayi (Hooker, 1886): Maingay 2456 [Kew distribution $n r$. 1270], which was collected in Malacca. There are two specimens of this gathering at $\mathrm{K}$, one with flowers, fruits and drawings on the sheet and another with fruits and detailed notes. The first specimen, K000009823, is selected here as the lectotype. 
Endiandra praeclara Gamble, Bull. Misc. Inform. Kew 1910: 152 (1910); Ridley, Fl. Malay Penins. 3: 90 (1924); Kochummen, Tree Fl. Malaya 4: 143 (1989). - TYPE: [Peninsular Malaysia] Perak, at Tupai, September 1888, L. Wray 3097 (lectotype K [K000009816], designated here; isolectotypes K [K000009815, K000009825]).

Several gatherings were mentioned in the original description of Endiandra praeclara (Gamble, 1910): King's Collector 4074, 6714 and L. Wray 3097, which are all very similar. Specimens of these gatherings are housed at several herbaria but as Gamble was working at Kew at the time he described this species, only the K material is considered for lectotypification. One sheet, L. Wray 3097 [K000009816], has the original floral dissections and drawings on a card made by Gamble and so it is designated here as the lectotype.

Endiandra scrobiculata Kosterm. ex Kochummen, Gard. Bull. Singapore 43: 25 (1992 ['1991']); Kochummen, Tree Fl. Malaya 4: 143 (1989). - TYPE: [Peninsular Malaysia] Pahang, Fraser's Hill, 15 November 1937, Symington KEP 45477 (lectotype KEP [35266], designated here).

Two gatherings were mentioned in the original description of Endiandra scrobiculata (Kochummen, 1992): Symington KEP 45477 and KEP 93366. Of these two, the specimen Symington KEP 45477 is designated here as the lectotype.

Endiandra rubescens (Blume) Miq., Pl. Jungh. 1: 176 (1852); Ridley, Fl. Malay Penins. 3: 89 (1924); Kochummen, Tree Fl. Malaya 4: 143 (1989). - Dictyodaphne rubescens Blume, Mus. Bot. 1 (17): 270 (1850). - TYPE: [Indonesia] Sumatra, C.F.E. Praetorius s.n. (lectotype L [L0036428], designated here; isolectotype L [L0036429]).

Only one gathering was mentioned in the original description of Dictyodaphne rubescens (Blume, 1850): Praetorius from Sumatra. Two very similar specimens of this gathering are at L and L0036428 is selected here as the lectotype.

Endiandra wrayi Gamble, Bull. Misc. Inform. Kew 1910: 152 (1910); Ridley, Fl. Malay Penins. 3: 89 (1924); Kochummen, Tree Fl. Malaya 4: 143 (1989). TYPE: [Peninsular Malaysia] Upper Perak, July 1889, L. Wray 3785 (lectotype K [K000009748], designated here, picture at KEP; isolectotype K [K000009747]).

Only one gathering was mentioned in the original description of Endiandra wrayi (Gamble, 1910): Wray 3785, which was collected in Upper Perak. There are two specimens of this gathering at $\mathrm{K}$, both with fruits. One specimen has one fruit and the other has two, and the latter, K000009748, is selected here as the lectotype. 
Lindera bibracteata (Blume) Boerl., Handl. Fl. Ned. Ind. 3: 146 (1900); Ridley, Fl. Malay. Pen. 3: 136 (1924); Kochummen, Tree Fl. Malaya 4: 145 (1989); Ng, Gard. Bull. Singapore 57: 243 (2005). - Laurus bibracteata Blume, Bijdr. Fl. Ned. Ind. 11: 553 (1826). - Daphnidium bibracteatum (Blume) Nees, Syst. Laur. 615 (1836). - Benzoin bibracteatum (Blume) Kuntze, Revis. Gen. Pl. 2: 569 (1891). - TYPE [Indonesia, Java] Gede, Salak, C.L. Blume s.n. (lectotype L [L0036469], designated here).

In the original description of this taxon, Blume (1826) mentioned that the type was collected in June from Mt Gede, Salak. There are four morphologically very similar specimens with at least part of the locally data available at L for lectotypification [L0036469, L0036470, L0036471 and L0036472]. The specimen L0036469 is designated here as the lectotype.

Lindera polyantha (Blume) Boerl., Handl. Fl. Ned. Ind. 3: 147 (1900); Ridley, Fl. Malay Penins. 3: 135 (1924). - Benzoin polyanthum (Blume) Kuntze, Revis. Gen. P1. 2: 569 (1891). - Polyadenia polyantha (Blume) Nees, Syst. Laur. 577 (1836). Aperula polyantha (Blume) Blume, Mus. Bot. 1 (21): 366 (1851). - Laurus polyantha Blume, Bijdr. Fl. Ned. Ind. 11: 554 (1826). - TYPE: [Indonesia] Burangrang Prov., Krawang, July, C.L. Blume [1469] (lectotype L [L0036535], designated here).

In the original description, Blume (1826) mentioned that the material on which this name is based was collected in July at Krawang in the province of Burangrang, which is in West Java, Indonesia. There are five different sheets available for lectotypification at L. Several are sterile or only have flowers [L0036532, L0036533, L0036534, L0036536] and only one specimen has both flowers and fruits [L0036535] and is designated here as the lectotype.

Lindera wrayi Gamble, Bull. Misc. Inform. Kew 1910: 367 (1910); Ridley, Fl. Malay Penins. 3: 134 (1924); Kochummen, Tree Fl. Malaya 4: 148 (1989). TYPE: [Peninsular Malaysia] Pahang, Gunung Brumbu, L. Wray 1564 (lectotype K [K000815581], designated here).

Several gatherings are mentioned in the original description of Lindera wrayi (Gamble, 1910): Wray 399, 1564, 3866, 4149; Ridley 9706 and Scortechini s.n., which are all morphologically similar. Of these, one of the K specimens of Wray 1564 [K000815581] has a card in an envelope with the original floral dissections and drawings made by Gamble. This specimen is designated here as the lectotype.

Litsea foliosa Nees var. caesia Meisn. in DC., Prodr. 15: 222 (1864). - TYPE: [Peninsular Malaysia] Malacca, W. Griffith s.n. [Kew distribution nr. 4331] (lectotype K [K000815652], designated here). 
Three different gatherings are mentioned in the original description of Litsea foliosa var. caesia (Meisner, 1864): Wallich 2568A from Penang, Wallich 2568B from Singapore and Griffith s.n from Malacca. Meisner also mentioned that he has seen this material either in the herbaria in B, G or in Hooker's herbarium. The specimen of Griffiths s.n. [Kew distribution $n r$. 4331] [K000815652] with the stamp of Hooker's herbarium has the original label and many flowers and is designated here as the lectotype.

Machilus odoratissima Nees var. glabrata Meisn. in DC., Prodr. 15: 41 (1864). TYPE: Singapore, 1822, N. Wallich 2607f (lectotype K-W [K001116557], designated here).

In the original description of Machilus odoratissima var. glabrata (Meisner, 1864), two distinct gatherings were mentioned: Wallich $2607 f$ collected in Singapore in 1822 and Wallich $2607 B$ collected in Nepal. The K-W specimen of the first gathering is selected here as the lectotype.

Machilus rimosa (Blume) Blume, Mus. Bot. 1 (21): 330 (1851). - Laurus rimosa Blume, Bijdr. F1. Ned. Ind. 11: 574 (1826). - TYPE: [Indonesia] Java, Tjiburrum, Gede, mountain forest, 'Huru hiries', C.G.C. Reinwardt s.n. [lectotype L [L0036954], designated here).

In the original description, Blume (1826) mentioned that the material on which this name is based was collected by C.G.C. Reinwardt, with the local name Huru hiries, in the mountain forests of Gede in Java. There are three very similar sheets available for lectotypification at L [L0036953, L0036954, L0036955]. Of these, only one has both the collector's name and the common name mentioned on the label, L0036954, and this specimen is designated here as the lectotype.

Neolitsea cinnamomea (Ridl.) Kosterm., Reinwardtia 6: 287 (1962); Kochummen, Tree Fl. Malaya 4: 148 (1989). - Lindera cinnamomea Ridl., J. Fed. Malay. States Mus. 6: 173 (1915). - TYPE: [Peninsular Malaysia] Gunung Tahan, July 1911, H.N. Ridley 16124 (lectotype K [K000815498], designated here; isolectotypes BM [no barcode], K [K000815497).

There is only one gathering mentioned in the original description of Lindera cinnamomea (Ridley, 1915): Ridley 16124, of which there are two specimens at K and one at BM. The specimen K000815498, which has an original label, is designated here as the lectotype. 
Neolitsea kedahense (Gamble) Gamble, Bull. Misc. Inform. Kew 1911: 172 (1911); Ridley, Fl. Malay Penins. 3: 132 (1924); Kochummen, Tree Fl. Malaya 4: 168 (1989). - Tetradenia kedahensis Gamble, Bull. Misc. Inform. Kew 1910: 367 (1910). - TYPE: [Peninsular Malaysia] Kedah, Kedah Peak, June 1893, H.N. Ridley 5490 (lectotype K [K000815496], designated here; isolectotype BM [no barcode]).

Two gatherings were mentioned in the original description of Tetradenia kedahensis (Gamble, 1910): Ridley 3590 and 5490, both from Kedah Peak in Kedah, Peninsular Malaysia and all specimens are housed either at K or BM. As Gamble was working at Kew at the time he described this species, only the $\mathrm{K}$ material is considered for lectotypification. Ridley 5490 [K000815496] has infloresences with the dissections and drawings on a card signed by Gamble, as typical for this author, and this sheet is designated here as the lectotype.

Neolitsea mollissima (Gamble) Gamble, Bull. Misc. Inform. Kew 1911: 172 (1911); Ridley, Fl. Malay Penins. 3: 132 (1924); Kochummen, Tree Fl. Malaya 4: 168 (1989). - Tetradenia mollissima Gamble, Bull. Misc. Inform. Kew 1910: 366 (1910). TYPE: [Peninsular Malaysia] Perak, Gunung Batu Putih, L. Wray 931 (lectotype K [K000815494], designated here; isolectotype [K000815495]).

Only one gathering was mentioned in the original description of Tetradenia mollissima (Gamble, 1910): L. Wray 931, for which there are two specimens at K. Both have flowers but one of them also has the dissections and drawings on a card signed by Gamble, which is typical for this author, and this specimen, K000815494, is designated here as the lectotype.

Phoebe cuneata (Blume) Blume, Mus. Bot. 1 (21): 326 (1851); Ridley, Fl. Malay Penins. 3: 106 (1924). - Persea macrophylla var. cuneata Blume, Bijdr. Fl. Ned. Ind. 11: 568 (1826). - Machilus cuneata (Blume) Hassk., Cat. Hort. Bot. Bogor. 88 (1844). - Euphoebe cuneata (Blume) Meisn., Prodr. 15: 58 (1864). - Alseodaphne cuneata (Blume) Boerl., Handl. Fl. Ned. Ind. 3: 137 (1900). - TYPE: [Indonesia] Java, 'kittailas Badas', C.L. Blume s.n. (lectotype L [L0036859], designated here).

In the original description, Blume (1826) mentioned that the material on which this name is based was collected in February, with the local name Kittailas Badas, in the forest at Seribu in West Java, Indonesia. There are five very similar sheets available for lectotypification at L [L0036856, L0036857, L0036858, L0036859, L0036860]. Of these, one, L0036859, has some of the information from the original description on the label including the common name so this specimen is designated here as the lectotype. 
Phoebe elliptica Blume, Mus. Bot. 1 (21): 326 (1851); Kochummen, Tree Fl. Malaya 4: 176 (1989). - TYPE: [Indonesia] Java, in Mountains, C.L. Blume s.n. (lectotype L [L0036885], designated here).

In the original description, Blume (1851) mentioned that the material on which this name is based was collected in the mountains of Java. There are two very similar specimens available for lectotypification at L [L0036884 and L0036885]. One of these, L0036885, has an original label and is therefore designated here as the lectotype.

Phoebe kunstleri Gamble, Bull. Misc. Inform. Kew 1910: 226 (1910); Ridley, F1. Malay Penins. 3: 105 (1924). - TYPE: [Peninsular Malaysia] Perak, near Goping, September 1885, H.H. Kunstler 8173 (lectotype K [K000778870], designated here; isolectotypes K [K000778869 and two with no barcode], MEL [MEL2390378], P [P00752546]).

Several gatherings are mentioned in the original description of Phoebe kunstleri (Gamble, 1910): Haviland s.n. from Sarawak, Kunstler 4491, 6180, 8173, Scortechinii 497 and Wray 3964 from Peninsular Malaysia and Ridley 5915 from Singapore, which are all morphological very similar. Of these, one of the sheets of Kunstler 8173 at $\mathrm{K}$ [K000778870] has a card in an envelope with the original floral dissections and drawings made by Gamble. This specimen is designated here as the lectotype.

Phoebe macrophylla (Nees) Blume, Mus. Bot. 1 (21): 326 (1851); Ridley, Fl. Malay Penins. 3: 105 (1924). - Machilus macrophylla Nees, Syst. Laur. 674 (1836). - TYPE: [Indonesia] Java, Salak, Gede, C.L. Blume s.n. (lectotype L [L0036882], designated here).

In the original description, Nees von Esenbeck (1836) mentioned that the material on which this name is based was collected from Gede, near Salak, in West Java. There are four very similar sheets available for lectotypification at L [L0036880, L0036881, L0036882, L0036883]. Of these, the sheet L0036882, which has the most mature fruits and erect, stiff perianth lobes, is designated here as the lectotype.

Tetradenia furfuracea Wall. ex Nees in Wallich, P1. Asiat. Rar. 2: 64 (1831). - TYPE: Singapore, 1822, Wallich 2568 a (lectotype GZU [GZU 000254222], designated here; isolectotype $\mathrm{K}$ [K000815651]).

Two different gatherings were mentioned in the original description of Tetradenia furfuracea (Nees von Esenbeck, 1831): Wallich 2568b, collected in Penang and Wallich 2568a, collected in Singapore. The collections of Lauraceae studied by Nees von Esenbeck are at GZU, and therefore only GZU material is considered for 
lectotypification. Of the two GZU specimens (GZU000254222 and GZU 000254225), the sheet of Wallich 2568a [GZU 000254222] with mature flowers is designated here as the lectotype.

ACKNOWLEDGEMENTS. The author is grateful to the curators of the BM, GH, K, KEP, L, P, $\mathrm{U}$ and SING herbaria for access of the specimens used in the present study. I am very grateful to Helen Hopkins for checking my English. The drawings were made by Adnan B. Mohammad. In FRIM I would like to thank Dr Ruth Kiew, Dr Richard Chung, Dr Yap Jing Wei and Siti Munirah Bt. Mat Yunoh for all their help. This research was supported by two Visiting Research Fellowships at FRIM and two Research Fellowships at the Singapore Botanic Gardens, which are gratefully acknowledged.

\section{References}

Blume, C.L. (1826). Bijdragen tot de Flora van Nederlansch Indië. 11. Batavia: Ter Lands Drukkerij.

Blume, C.L. (1850). Museum Botanicum Lugduno-Batavum, vol. 1 (17). Leiden.

Blume, C.L. (1851). Museum Botanicum Lugduno-Batavum, vol. 1 (21). Leiden.

de Kok, R.P.J. (2016a). A revision of Beilschmiedia (Lauraceae) of Peninsular Malaysia. Blumea 61: 147-164.

de Kok, R.P.J. (2016b). A revision of Cryptocarya R.Br. (Lauraceae) of Peninsular Malaysia. Kew Bull. 71(7): 1-16.

de Kok, R.P.J. (2016c). Notes on the monotypic genus Hexapora (Lauraceae), endemic to Peninsular Malaysia. Gard. Bull. Singapore 68(2): 201-208.

de Kok, R.P.J. (2019). A revision of Cinnamomum Schaeffer (Lauraceae) of Peninsular Malaysia. Gard. Bull. Singapore 71(1): 89-139.

Gamble, J.S. (1910). New Lauraceae from the Malayan region I. Bull. Misc. Inform. Kew 1910: $142-153$.

Gamble, J.S. (1912). Materials for a Flora of the Malayan Peninsula, no 22. J. Asiatic Soc. Bengal, Pt. 2, Nat. Hist. 75: 1-204.

Hooker, J.D. (1886). Flora of British India, vol. 5. London: L. Reeve.

Julia, S. (2005). A Synopsis of the Genus Actinodaphne Nees (Lauraceae) in Sabah and Sarawak, Malaysia. Gard. Bull. Singapore 57: 69-100.

Kochummen, K.M. (1989). Lauraceae. In: Ng, F.S.P. (ed.) Tree Flora of Malaya, vol. 4, pp. 98-178. Malaysia: Longman.

Kochummen, K.M. (1992 ['1991]). Notes on the Systematy of Malayan Phanerogams XXXI Lauraceae. Gard. Bull. Singapore 43: 23-26.

Kostermans, A.J.G.H. (1962). The Asian species of Persea Mill. (Lauraceae). Reinwardtia 6(2): 189-194.

Lecomte, H. (1914). Lauracées. In: Lecomte, M.H. \& Gagnepain, F. (eds) Flore Générale de L'Indo-Chine 5, pp. 107-158. Paris: Masson et Cie.

Li, H.W., Li, J., Huang, P.H.,, Wei, F.N., Cui, H.B. \& van der Werff, H. (2008). Lauraceae. In: Wu, Z.Y., Hong, D.Y. \& Raven, P.H. (eds) Flora of China, vol. 7, pp. 102-254. Beijing: Science Press and St. Louis: Missouri Botanical Garden. 
Meissner, C.D.F. (1864). Lauraceae. In: De Candolle, A. (ed) Prodromus Systematis Naturalis 15, pp. 1-260. Parisii: Sumptibus Sociorum Treuttel et Würtz.

Nees von Esenbeck, C.G.D. (1831). Lauraceae. In: Wallich, N. Plantae Asiaticae Rariores, vol. 2, pp. 58-76. London.

Nees von Esenbeck, C.G.D. (1836). Systema Laurinarum. Berolini: Sumptibus Veitii et Sociorum.

Ridley, H.N. (1915). The Botany of Gunung Tahan. J. Fed. Malay. States Mus. 6: 127-202.

Rohwer, J.G. (1993). Lauraceae. In: Kubitzki, K., Rohwer, J.G. \& Bittrich, V. (eds) The Families and Genera of Vascular Plants, vol. 2, pp. 366-391. Berlin: Springer-Verlag.

Rohwer, J.G., Li, J., Rudolph, B., Schmidt, S.A., van der Werff, H. \& Hsi-wen, L. (2009). Is Persea (Lauraceae) Monophyletic? Evidence from Nuclear Ribosomal ITS sequences. Taxon 58: 1153-1167.

Rumphius, G.E. (1743). Herbarium Amboinense, vol. 3. Amsterdam.

Tanaros, M., Vajrodaya, S. \& Chayamarit, K. (2010). Taxonomic study of the genus Actinodaphne Nees (Lauraceae) in Thailand. Thai J. Bot. 2(1): 7-23.

Turland, N.J., Wiersema, J.H., Barrie, F.R., Greuter, W., Hawksworth, D.L., Herendeen, P.S., Knapp, S., Kusber, W.-H., Li, D.-Z., Marhold, K., May, T.W., McNeill, J., Monro, A.M., Prado, J., Price, M.J. \& Smith, G.F. (2018). International Code of Nomenclature for algae, fungi, and plants (Shenzhen Code) adopted by the Nineteenth International Botanical Congress Shenzhen, China, July 2017. Regnum Vegetabile 159. Glashütten: Koeltz Botanical Books.

van der Werff, H. (2001). An annotated key to the genera of Lauraceae in the Flora Malesiana Region. Blumea 46: 125-140. 